\title{
Climatic records in a firn core from an Alpine temperate glacier on Mt. Yulong, southeastern part of the Tibetan Plateau
}

\author{
Cold and Arid Regions Environmental and Engineering Research Institute, Chinese Academy of Sciences, Lanzhou 73000, China.
}

\begin{abstract}
Mt. Yulong is the southernmost glacier-covered area in Eurasia, including China. There are 19 sub-tropical temperate glaciers on the mountain, controlled by the southwestern monsoon climate. In the summer of 1999, a firn core, $10.10 \mathrm{~m}$ long, extending down to glacier ice, was recovered in the accumulation area of the largest glacier, Baishui No.1. Periodic variations of climatic signals above $7.8 \mathrm{~m}$ depth were apparent, and net accumulation of four years was identified by the annual oscillations of isotopic and ionic composition. The boundaries of annual accumulation were confirmed by higher values of electrical conductivity and $\mathrm{pH}$, and by dirty refreezing ice layers at the levels of summer surfaces. Calculated mean annual net accumulation from 1994/1995 to 1997/1998 was about $900 \mathrm{~mm}$ water equivalent. The amplitude of isotopic variations in the profile decreased with increasing depth, and isotopic homogenization occurred below $7.8 \mathrm{~m}$ as a result of meltwater percolation. Variations of $\delta^{18} \mathrm{O}$ above $7.8 \mathrm{~m}$ showed an approximate correlation with the winter climatic trend at Lijiang station, $25 \mathrm{~km}$ away. Concentrations of $\mathrm{Ca}^{2+}$ and $\mathrm{Mg}^{2+}$ were much higher than those of $\mathrm{Na}^{+}$and $\mathrm{K}^{+}$, indicating that the air masses for precipitation were mainly from a continental source, and that the core material accumulated during the winter period. The close correspondence of $\mathrm{Cl}^{-}$and $\mathrm{Na}^{+}$indicated their common origin. Very low concentrations of $\mathrm{SO}_{4}{ }^{2-}$ and $\mathrm{NO}_{3}{ }^{-}$suggest that pollution caused by human activities is quite low in the area. The mean annual net accumulation in the core and the estimated ablation indicate that the average annual precipitation above the glacier's equilibrium line is 2400-3150 mm, but this needs to be confirmed by long-term observation of mass balance.
\end{abstract}

\section{Introduction}

Mt. Yulong, located in the Hengduan Mountain Range, north of Lijiang, Yunnan Province, China $\left(27^{\circ} 10^{\prime}-27^{\circ} 40^{\prime} \mathrm{N}\right.$; $\left.100^{\circ} 07^{\prime}-100^{\circ} 10^{\prime} \mathrm{E}\right)$, is the southernmost glacierized area in Eurasia. There are 19 temperate glaciers on the mountain, controlled by the
Asian southwestern monsoon climate. Their total area is $11.61 \mathrm{~km}^{2}$. The glaciers resemble a group of flying dragons, giving Mt. Yulong (white dragon) as its name.

Many explorers, tourists, poets and scientists have described Mt. Yulong from different points of view (Ward, 1924; Wissmann, 1937). However, as they were unable to cross the extremely steep mountain slopes and the forested area to the glacier above $4000 \mathrm{~m}$ a.s.l., some reported data were not correct. Most of the literature has focussed on the alpine landscape and the snow scenery, and there are few accounts of the existing glaciers. Ren et al (1957) and Luo and Yang (1963) first reported the distribution of these glaciers and of the late Pleistocene glacial landforms. To clarify the scale of glaciation in China during the Quaternary, Xie and Cui (1989) investigated the distribution of Quaternary glacial landforms and Ice Ages. Pu (1994) produced a glacier inventory of the region. In 1982, a glaciological research group, composed of personnel from the Lanzhou Institute of Glaciology and Geocryology, Chinese Academy of Sciences, and the Geography Department of Lanzhou University, carried out relatively detailed, but short-term, observations related to existing glaciers, the snow cover and evidence of historic glacier variations on Mt. Yulong (Li and Su, 1996). Since 1996, Mt. Yulong has been developed into a famous glacier park in China, open to tourists from different parts of the world, and it provides excellent conditions for glaciological investigations. To meet the requirements of glacial tourism, Zhao et al. (1999) and Zheng (2000) summarized the features of glacial geomorphology and the course of glaciation during the Pleistocene.

Several advanced methods, such as the analysis of environmental records in snow and ice, quantitative analysis of hydrochemical changes, monitoring of recent glacier changes and measurements of mass balance, have not been applied in glaciological studies on Mt. Yulong. In particular, there is a dearth of measured climatic data from above $4500 \mathrm{~m}$ a.s.l. In order to fill these gaps and to start a new study of contemporary processes at temperate glaciers in China, fieldwork based on ice core drilling was carried out between June and July 1999. A shallow core, $10.10 \mathrm{~m}$ long, through firn to glacier ice, was recovered in the accumulation area (4950 ma.s.1.) of the largest glacier on Mt. Yulong, Baishui No.1 (Figure 1). Here we focus on the significance of the climatic signals recorded in the core.

\section{Climate and glaciers in the study area}

There are 15 glaciers, with a total area of $10.86 \mathrm{~km}^{2}$, on the eastern slope of Mt. Yulong. The largest one, Baishui No.1, has an area of $1.52 \mathrm{~km}^{2}$ and a length of $2.7 \mathrm{~km}$ (Figure 1). The broad, flat accumulation area covers about $1.0 \mathrm{~km}^{2}$. The altitude of the equilibrium line is around $4800 \mathrm{~m}$ and the glacier ends at about $4100 \mathrm{~m}$. Abundant crevasses in the ablation area reflect the very active glacier motion. Mt. Yulong is located in the subtropical zone influenced by the South Asia/Indian monsoon, and most precipitation falls between June and September, originating from moisture-rich air masses of the south- 


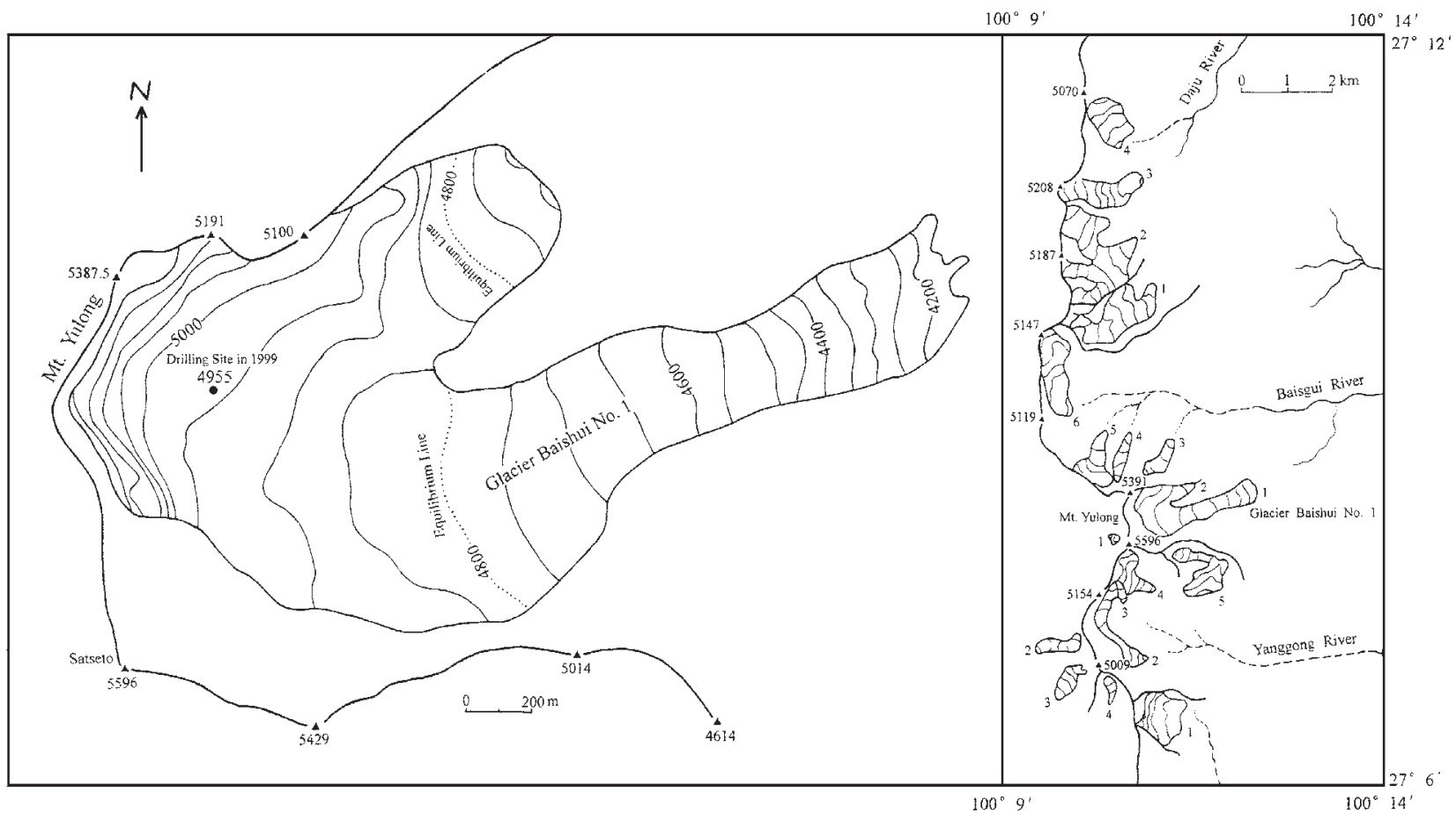

Figure 1 Distribution of glaciers on Mt. Yulong (right) and the largest glacier, Baishui No.1, with the 1999 drilling site in the accumulation area (left).

eastern summer monsoon. Winter is relatively dry, controlled by the winter monsoon of continental origin.

The measured data of mean annual temperature and precipitation at Lijiang meteorological station (2393 ma.s.1.), $25 \mathrm{~km}$ from Mt. Yulong, indicate the climatic trends in the region in the past 50 years (Figure 2). The mean annual temperature is $12.6^{\circ} \mathrm{C}$, with a positive mean temperature in every month. According to the upper air data at Lijiang station, at $5400 \mathrm{~m}$, the mean annual temperature is about $7.5^{\circ} \mathrm{C}$ and the mean temperature is below $0^{\circ} \mathrm{C}$ in every month. The mean annual temperature around the equilibrium line $(4800-5000$ ma.s.1.) is $-3.3^{\circ} \mathrm{C}$ to $-4.7^{\circ} \mathrm{C}$ (Wang, 1996). Using the $772 \mathrm{~mm}$ multiyear mean precipitation at Lijiang station and a calculated gradient of $103.3 \mathrm{~mm} / 100 \mathrm{~m}$ of precipitation, $\mathrm{Su}$ and $\mathrm{Pu}$ (1996) estimated that the precipitation above the equilibrium line ranged between 2383 $\mathrm{mm}$ and $2590 \mathrm{~mm}$. These climatic conditions make Mt. Yulong the southernmost region for development of glaciers in China. The glaciers on Mt. Yulong are characterized by large amounts of accumulation and ablation, high temperatures, basal sliding and rapid movement; they are typical sub-tropical temperate glaciers ( $\mathrm{Li}$ and $\mathrm{Su}$, 1996).

\section{Methods and results}

On July 2, 1999, a 10.10m long core was drilled at $4950 \mathrm{~m}$ in the accumulation area of the glacier Baishui No. 1, using a US-made PICO corer. 101 samples, each $0.1 \mathrm{~m}$ long, were collected. The samples were processed in the field by cutting with a clean stainless knife, to obtain a contamination-free centre sample. Table tops and tools were modified or covered with plastic. Samples then were transferred to polyethylene bags for further processing. Each sample was melted at about $20^{\circ} \mathrm{C}$ in a clean plastic bag, and the meltwater was poured into a pre-cleaned high-density polyethylene bottle; the bottle top was sealed with wax to avoid evaporation or diffusion. Bottled samples were transported to the Laboratory of Ice Core and Cold Region Environment, Chinese Academy of Sciences, and kept in a cold room at $-20^{\circ} \mathrm{C}$ until $\delta^{18} \mathrm{O}$, $\mathrm{Na}^{+}, \mathrm{Ca}^{2+}, \mathrm{Mg}^{2+}, \mathrm{Cl}^{-}$, conductivity and $\mathrm{pH}$ values were determined using a Finngan MAT-252 Spectrometer (precision 0.5\%o), Dinex100 chromatography (precision $0.1 \%$ ), 2380 Atomic Absorption Spectrophotometer (precision $0.2 \%$ ), conductivity and $\mathrm{pH}$ meters. The results are shown in Figures 3 and 4.

\section{Stable oxygen isotopes}

The distribution of $\delta^{18} \mathrm{O}$ values in the core (Figure 3) displays periodic variations. These are the largest between the surface and $3.5 \mathrm{~m}$ depth. The amplitude of the variations decreases from $3.5 \mathrm{~m}$ to 7.8 $\mathrm{m}$, below which the $\delta^{18} \mathrm{O}$ values have been smoothed and no variations are apparent. This resembles the general distribution of $\delta^{18} \mathrm{O}$ values in snow and ice in the accumulation areas of temperate glaciers (Oerter et al., 1985; Delmas et al., 1985; Wagenbach, 1989; He, 1993; He and Theakstone, 1994; Raben and Theakstone, 1997, Matsuoka, 1999). Five net accumulation layers could be identified from

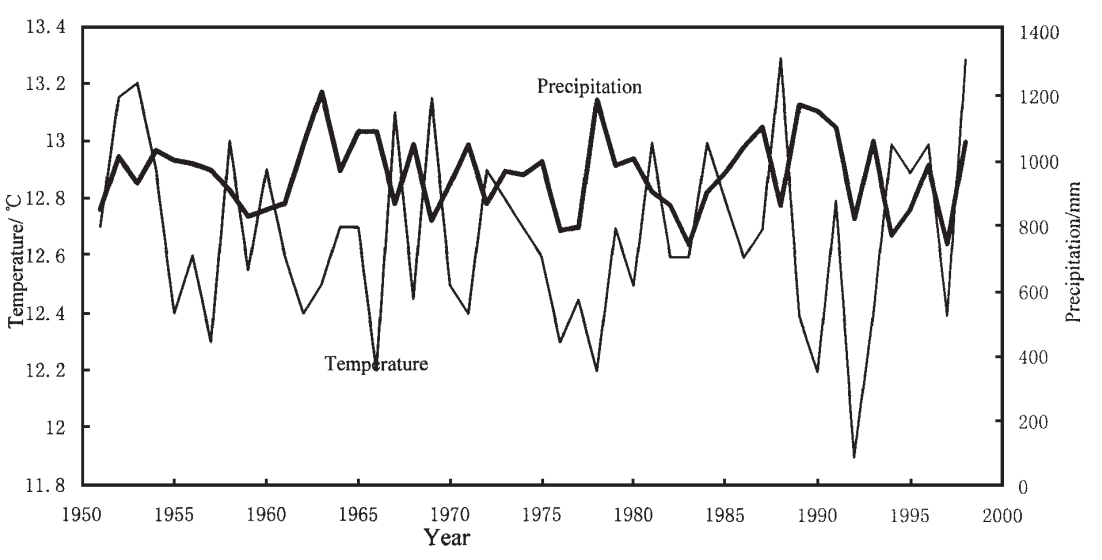

Figure 2 Mean annual temperature and precipitation at the Lijiang meteorological station, $25 \mathrm{~km}$ north to the Mt. Yulong, 1951-1998. 


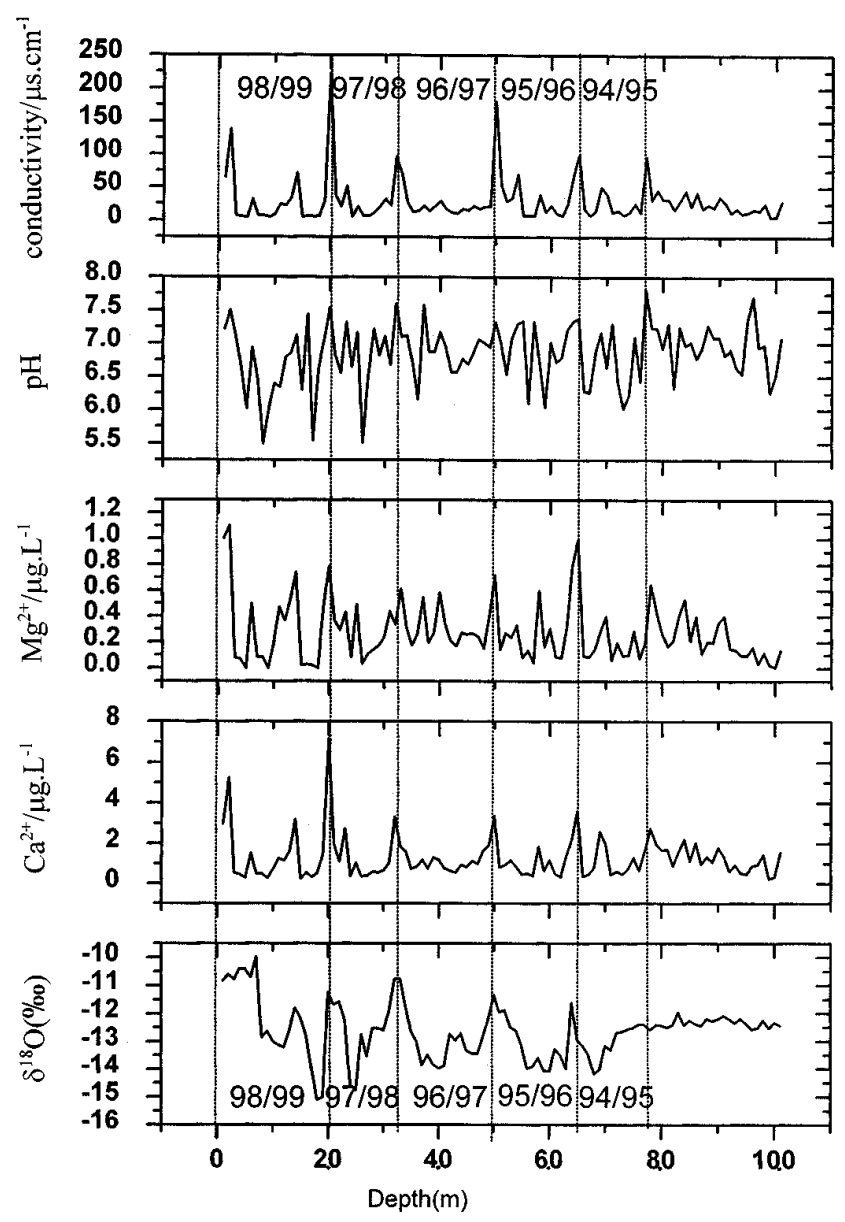

Figure 3 Profiles of $\delta^{18} \mathrm{O}, \mathrm{Ca}^{2+}, \mathrm{Mg}^{2+}, \mathrm{pH}$ and conductivity values in the $10.10 \mathrm{~m}$ core collected in 1999, with the identified net accumulation of five years.

the periodic variations of the $\delta^{18} \mathrm{O}$ values in the core, with their abrupt changes between higher and lower values. These were at depths of 0-2.0 m, 2.0-3.2 m, 3.2-5.0 m, 5.0-6.5 $\mathrm{m}$ and 6.5-7.8 m, corresponding to the balance years 1998/99, 1997/98, 1996/97, $1995 / 96$ and 1994/95, respectively. The top of each layer can be regarded as the summer surface of the associated balance year. The uppermost layer was still influenced by summer melting. The net accumulation of the previous four years was $1.2 \mathrm{~m}, 1.8 \mathrm{~m}, 1.5 \mathrm{~m}$ and $1.3 \mathrm{~m}$; these values correspond well with some peak values of conductivity, $\mathrm{pH}$ and ionic concentrations (Figure 3). The locations of the summer surfaces were confirmed by the dirty melted-refreezing ice layers observed at those depths during structural observations of the ice core in the field (Figure 4); the ice layers in the snow and firn included an $8.0 \mathrm{~cm}$ thick layer at a depth of $2.0 \mathrm{~m}$ and an $8.5 \mathrm{~cm}$ thick layer at $3.2 \mathrm{~m}$.

The variations of $\delta^{18} \mathrm{O}$ values within an annual layer represent air temperature trends during precipitation events. The decreasing amplitude between the surface and $7.8 \mathrm{~m}$, and smoothed values below $7.8 \mathrm{~m}$, reflect a gradual homogenization process caused by meltwater percolation. Percolation is hindered by ice layers, which reduce its effect on the climatic signals in the core. Thus, in recent years, climatic information has been retained in the melting snow and ice in the accumulation area of the temperate glacier. According to the observations made at about $4800 \mathrm{~m}$ on the glacier by $\mathrm{Su}$ and $\mathrm{Pu}$ (1996) between June and July 1982, strong ablation occurred in the accumulation area. The temperature was close to the melting

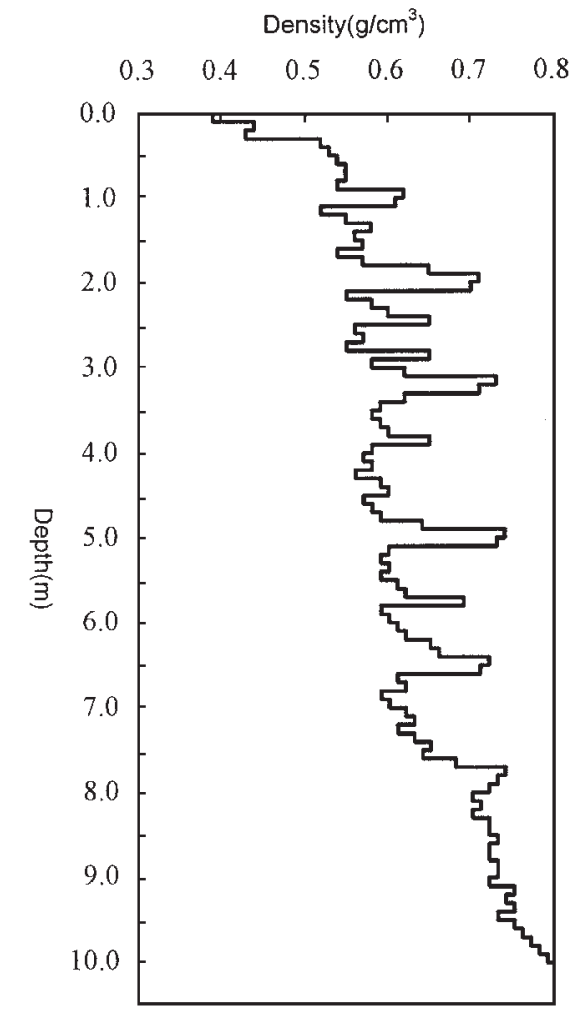

Figure 4 Densities of 101 samples, each $0.10 \mathrm{~m}$ long in the core collected at the glacier Baishui No.1 in July 1999. A slow increase down to $7.8 \mathrm{~m}$ depth is interrupted by abrupt increases at ice layers formed by meltwater refreezing. These layers coincide with summer surfaces identified by chemical analyses.

point in the uppermost $2 \mathrm{~m}$ of snow, but decreased to below $0^{\circ} \mathrm{C}$ between $2.0 \mathrm{~m}$ and $8.2 \mathrm{~m}$. There was a slight increase below $8.2 \mathrm{~m}$. These observations indicate a stronger influence of meltwater percolation in the uppermost $2.0 \mathrm{~m}$ and a reduced effect below that depth.

$\delta^{18} \mathrm{O}$ values between the surface and $7.8 \mathrm{~m}$ are roughly correlated with the variations of temperature and precipitation at Lijiang station during the winter months between the balance years of $1998 / 99$ and 1994/95 (Figure 5). The within-year variations of $\delta^{18} \mathrm{O}$ values suggest a warmer period between October and November, a colder period from December to February and a warmer period between March and May during the winter season of each balance year. Below $7.8 \mathrm{~m}$, however, the climatic records are smoothed as a result of a slowly occurring homogenization process.

\section{Ionic analysis}

Analyses of the main cations $\left(\mathrm{Ca}^{2+}, \mathrm{Mg}^{2+}, \mathrm{Na}^{+}\right)$revealed a pronounced correspondence between cationic concentrations and the isotopic profile (Figure 3). Peak values of cationic content appear at the depths of identified summer surfaces and the positions of thick dirty ice layers. The highest concentrations are of $\mathrm{Ca}^{2+}$, and the lowest of $\mathrm{Na}^{+} . \mathrm{Mg}^{2+}$ variations are similar to that of $\mathrm{Ca}^{2+}$. Concentrations of $\mathrm{Ca}^{2+}$ and $\mathrm{Mg}^{2+}$ are much higher than that of $\mathrm{Na}^{+}$; this reflects the fact that more of the impurities in the core came from a continental source than from a marine one. Because of the positive mean air temperature in the study area between July and September, most materials in the core are inferred as having been deposited during the winter season, between October and May. Winter air masses, forced upwards by the blocking mountain, carry more land-surface impurities, resulting in the higher concentrations of $\mathrm{Ca}^{2+}$ and $\mathrm{Mg}^{2+}$.

There is a significant relationship between $\mathrm{Cl}^{-}$and $\mathrm{Na}^{+}$(Figure 6), indicating their common source. Extremely low concentrations of $\mathrm{SO}_{4}{ }^{2-}$ and $\mathrm{NO}_{3}{ }^{-}$reflect the very slight pollution by human activity in 
the study area. $\mathrm{SO}_{4}{ }^{2-}$ and $\mathrm{NO}_{3}-$ could not be detected in most of the core samples. These two anions were found in very low concentrations only at depths of $1.5 \mathrm{~m}, 4.5 \mathrm{~m}, 5.0 \mathrm{~m}, 7.4 \mathrm{~m}$ and $8.0 \mathrm{~m}$, suggesting that slight pollution is associated occasionally with some large-scale atmospheric events. In general, the glacier-covered area on Mt. Yulong is well protected and little influenced by human activities; there is no heavy industry in Lijiang district and there is a full cover of vegetation.

\section{pH and conductivity values}

A positive correlation exists between $\mathrm{pH}$ values and conductivity in the core (Figure 3), with some peak values at the depths of identified summer surfaces. $\mathrm{pH}$ and conductivity values also correlate well with the main ionic profiles, indicating that, where the ions were concentrated, the conductivity and alkalinity of the material were higher. In association with the isotopic profile, $\mathrm{pH}$ and conductivity can be used to identify the annual boundaries of the last five balance years.

\section{Discussion}

\section{Conservation and homogenization of climatic records in temperate snow and ice}

Most chemical records in snow and ice include variations caused by the influence of temperature conditions, accumulation amount and other factors such as meltwater percolation after deposition (Bales and Wolff, 1995; Raben and Theakstone, 1997). Accordingly, most ice core signals cannot coincide precisely with the original natural processes in the atmosphere. Knowledge about the processes of chemical changes from the atmosphere through snow to ice is limited, and this makes it difficult to interpret climatic information within ice cores quantitatively. High melting at an alpine temperate glacier has a great effect on the distribution of climatic records in snow and ice (He et al., 1999). Even in polar glaciers and ice sheets, the climatic information has been influenced by meltwater to some degree (Qin, 1995; Thompson et al., 1995; Hou et al., 1996).

As Mt. Yulong is located in a mild subtropical region, the low amount of solid precipitation at high altitude melts quickly at the glacier's surface in summer. Thus, net accumulated snow and ice preserved an incomplete record of a year and the material is deposited mainly in winter. Most signals in the core reported here are well correlated and clearly show climatic variations during the period of net accumulation in the last five years. A comparison of climatic records in the firn core and local climatic data demonstrates that the climatic information derived from the core is reliable (Figure 5). The gradually decreasing amplitude of isotopic variations in the $10.10 \mathrm{~m}$ core reflects homogenization of the climatic records by meltwater percolation. The homogenization process is closely associated with the duration and strength of meltwater percolation. In addition, it is also related to the physical structure of the snow and ice (Figure 4). As mentioned above, many refreezing ice layers, especially dirty and thick ice layers at the positions of identified summer surfaces (Figure 4), have blocked downward percolation of meltwater. The limited percolation and the negative temperatures below $2 \mathrm{~m}$ have preserved the record of recent years' climatic variations. During the summer, when snow and firn temperatures rise, melting may occur slowly, leading to homogenization. The percolation of meltwater also causes ions to move downwards at different rates, causing their redistribution.

Further studies of temporal changes of ions in snow and firn are needed. Shallow cores can lead to the recovery of climatic records for only a short period. However, it should be possible to find a high elevation and lower temperature site at one or more of the large temperate glaciers in the Bomi region of Tibet (Ding et al, 1995), where a deep ice core can be obtained and used to reconstruct the climatic history of a

Figure 6 The relationship between $\mathrm{Cl}^{-}$and $\mathrm{Na}^{+}$in the core from the glacier Baishui No.1 indicates their common source. 
longer period. This may provide a clear picture of the origin and historic evolution of the southwestern monsoon, as well as an estimation of atmospheric patterns and climatic features in the southeastern Tibetan plateau.

\section{Estimation of precipitation in the glacier's accumulation area}

By using multiple sources, the four years of net accumulation between 1994/95 and 1997/98 have been identified in the Mt. Yulong core, with respective thicknesses of $1.2 \mathrm{~m}, 1.8 \mathrm{~m}, 1.5 \mathrm{~m}$ and $1.3 \mathrm{~m}$. These are equal to the water equivalent of $819 \mathrm{~mm}, 945 \mathrm{~mm}$, $1134 \mathrm{~mm}$ and $756 \mathrm{~mm}$, respectively. With an average density of $0.63 \mathrm{~g} / \mathrm{cm}^{3}$, the mean net accumulation of the four years is $913.5 \mathrm{~mm}$ water equivalent. According to the definition of glacier mass balance, a glacier's balance year refers to an interval between the dates of two minimum thicknesses of the glacier (Paterson, 1981). The date is the end of an ablation period, that is the end of summer in a glacier's balance year, which generally occurs at the beginning of October. The annual firn thickness recovered in the core represents only a residual part of a year's total precipitation (net income in the accumulation area). If the incomes from avalanche and wind-blown snow are not considered, the annual precipitation at a high-melting temperate glacier equals the total accumulation:

$$
\mathrm{P}=\mathrm{A}+\mathrm{M}+\mathrm{E}
$$

where $\mathrm{P}$ is the total precipitation for the glacier's balance year, $\mathrm{A}$ is the net accumulation for that year, $\mathrm{M}$ is the amount of melting, and $\mathrm{E}$ is the total evaporation.

Between May and September, when the summer monsoon is dominant, there is little evaporation as the glacier's accumulation area is frequently enveloped in cloud and fog. Here, therefore, the evaporation caused by solar radiation is ignored. A significant part of the annual accumulation of snow is removed by the strong summer melting. Here, we use the net accumulation recovered from the 10.10 $\mathrm{m}$ core to estimate an approximate precipitation range in the accumulation area.

It is very difficult to estimate the snowmelt amount without the mass balance data. As observed between 26 June and 11 July, 1982 by Su and Wang (1996), the mean daily ablation in the lower part of the accumulation area and the area below the equilibrium line (4600 $\mathrm{m})$ was about $37 \mathrm{~mm}$ and $45 \mathrm{~mm}$ water equivalent, respectively, with a gradient of $4 \mathrm{~mm} / 100 \mathrm{~m}$ between them. Thus, it is inferred that the ablation in the middle part of the accumulation area was $25-30 \mathrm{~mm}$ water equivalent. Su and Wang (1996) noted that, during the warmest three months in summer (June, July and August), the daytime temperature in the accumulation area varied both positively and negatively; melting was higher in clear weather and lower in cloudy weather. Most night-time temperatures during the ablation period, between May and September, were negative, and little snowmelt occurred in the two colder months. When temperatures were negative, some meltwater re-froze in the snow or firn; this cannot be regarded as a net loss. Accordingly, it is estimated that the average daily ablation ranged between $10 \mathrm{~mm}$ and $15 \mathrm{~mm}$, and the total net ablation for the five months from May to September was 1500-2250 $\mathrm{mm}$ water equivalent. The sum of this ablation range and the 900 $\mathrm{mm}$ mean annual net accumulation recovered from the core indicates an approximate mean annual precipitation range of $2400-3150 \mathrm{~mm}$ in the glacier' accumulation area. Of course, this is just a rough estimation, which needs to be confirmed by long term mass balance measurements at the glacier.

\section{Conclusions}

Although the snow and firn at the temperate glacier Baishui No 1 were strongly influenced by meltwater, five winter's climatic records were evident in the $10.10 \mathrm{~m}$ firn core. These signals were protected by the dense refreezing ice layers within the snow and firn, which partially blocked, and so hindered, the downward percolation of meltwater. The variations of isotopic and ionic composition, $\mathrm{pH}$ and conductivity values indicate well the climatic changes during the five annual periods of net accumulation. Despite high melting of snow, the ice layers prevented the quick smoothing and mixture of the climatic information, and resulted in an amplitude-reduced pattern of climatic change during the winter seasons of recent years. The isotopic variations above $7.8 \mathrm{~m}$ depth correlate roughly with the differences of winter temperature and precipitation in the most recent five years.

As a result of slow and gradual meltwater percolation between the ice layers in summer, the amplitude of isotopic oscillations shows a reduced trend from the surface to a depth of $7.8 \mathrm{~m}$, and smoothing below this depth. This indicates a homogenization process of climatic signals at the alpine temperate glacier. However, because the dense ice layers hinder percolation, the climatic records maintained in the accumulated snow and firn for most recent years.

The concentrations of $\mathrm{Ca}^{2+}$ and $\mathrm{Mg}^{2+}$ are much higher than that of $\mathrm{Na}^{+}$, indicating that the materials in the core came mainly from a continental source and were carried by the winter monsoon. The $\mathrm{Cl}-$ and $\mathrm{Na}^{+}$contents of the core were significantly correlated, reflecting their common origin. Very low concentrations of $\mathrm{NO}_{3}{ }^{-}$and $\mathrm{SO}_{4}{ }^{2-}$ indicate that the pollution in the study area is quite slight. The relationship between $\mathrm{pH}$ values, conductivity and ionic concentrations indicates that the stratigraphic positions at which ions are concentrated are more alkaline and of higher conductivity.

The net accumulation in the core and the estimated snowmelt amount in the glacier's accumulation area indicate that the mean annual precipitation above the equilibrium line is within the range $2400-3150 \mathrm{~mm}$, but this needs to be confirmed by long-term mass balance measurements.

\section{Acknowledgements}

The work reported here was supported by the Innovation Fund (210019) of the Cold and Arid Regions Environmental and Engineering Institute, Cryospheric Changes and Their Impact on Resources and Environment in China (KZCX-2-301), Chinese Academy of Sciences, the Chinese Natural Science Foundation (40071023), the Special Fund for Cryospheric Studies (No.3), and the President's Selected Fund for Returned Overseas Researchers, from the Chinese Academy of Sciences. We received full support from the staff at the Laboratory of Ice Core and Cold Region Environment of the Chinese Academy of Sciences and support from the Tourism Company of Mt. Yulong during the field season in 1999. Dr. W.H. Theakstone in Manchester University gave useful comments about the paper. Zhang Yongliang and Liu Jingshou participated in the fieldwork. Sun Weizhen, Sheng Wenkun, Li Fengxia and Wang Xiaoxiang determined the $\delta^{18} \mathrm{O}$, cationic, anionic, $\mathrm{pH}$ and conductivity values in the laboratory.

\section{References}

Bales, R. C., and E W. Wolff, 1995, Interpreting natural climate signals in ice cores: EOS, American Geophysical Union, v.76, no.47, pp. 482-483.

Delmas, B. J., M. Legrand, and G. Holdsworth, 1985, Snow chemistry on Mount Logan, Yukon Territory, Canada: Annals of Glaciology 7, p.213.

Ding, L., Zhang, W., and Wang, N., 1994, The influence of precipitation on the development of glaciers in Bomi Region, Tibet, In: Proceeding of Natural Hazard Reduction and Mitigation in the East Asia, Japan, pp. 23-29.

He, Y., 1993, Chemical and physical studies of accumulated snow and firn at an alpine temperate glacier, Austre Okstindbreen, Okstindan, Norway, in relation to local climatic variations and regional atmospheric circulations: $\mathrm{Ph} . \mathrm{D}$. thesis, University of Manchester, England, pp.1-333.

He, Y., and W. H. Theakstone, 1994, Climatic influence on the composition of snow cover at Austre Okstindbreen, Okstindan, Norway, 1989-1990: Annals of Glaciology 19, pp.1-6.

He Y., Yao T., and W.H. Theakstone, 1999, Study on the climatic and environmental records of alpine temperate glacier, using the glacier Austre 
Okstindbreen as a sample: Journal of Glaciology and Geocryology, v.22, no.3, pp. 257-263.

Hou, S., Qin, D., and Huang, C., 1996, The preliminary analysis of meltwater percolation in snow stratigraphy at the glacier Dongkemadi in Mt. Tanggula: Journal of glaciology and Geocryology, v.18, no.3, pp. 227-234.

Li, J., and Su, Z., 1996. Glaciers in Hengduan Mountains, Science Press, pp.1-282.

Luo, L., and Yang, Y., 1963. Study of geomorphological formation in western Sichuan and northern Yunnan: Geography Bulletin 5, pp.1-47.

Matsuoka, K., and Naruse, R., 1999, Mass balance features derived from a firn core at Hielo Patagonico Norte, South America: Arctic, Antarctic and Alpine Research, v.31, no.4, pp.333-340.

Oerter, H., D. Baker, and W. Stichler, 1985, Isotope studies of ice cores from a temperate Alpine glacier (Vernagtferner, Austria) with respect to the meltwater flow: Annals of Glaciology 7, pp.90-93.

Paterson, W. S. B., 1981, The physics of glaciers: second edition, Pergamon Press, pp.1-276

Pu, J., 1994, The Glacier Inventory of China, The Changjiang (Yangtze) River Drainage Basin. Gansu Culture Press, pp.1-145.

Qin, D., 1995, The surface physical processes of snow and contemporary climatic and environmental records on Antarctic ice sheets. Science Press, Beijing, pp.1-202.

Raben, P., and W. H. Theakstone, 1997, Changes of ionic and oxygen isotopic composition snowpack at the glacier Austre Okstindbreen, Norway: Nordic Hydrology 29, pp.1-20.

Ren M., Liu Z., and Yong W., 1957, The preliminary studies of geomorphology in Lijiang and Mt. Yulong: Journal of Yunnan University. Edition of Natural Science Press 4, pp.9-18.

Dr. He Yuanqing is currently working as a professor of the Chinese Academy of Sciences (CAREERI, $C A S)$. He received Ph.D degree in 1993 and was undertaking his postdoctoral work in glacial geochemistry in 1994, based in Manchester University, England. then he was employed as an associate professor in glacial geology and geomorphology in Transkei University, South Africa in 1995. Now he is managing two research projects in Tibetan Plateau, dealing with glaciology and global change.

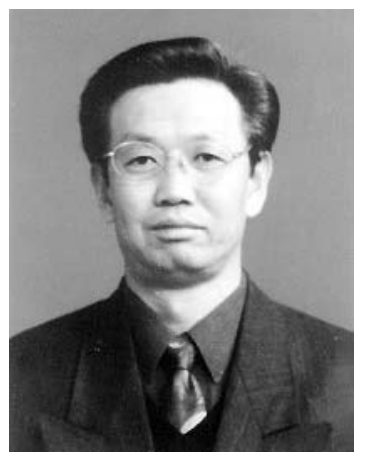

Professor Yao Tandong got his doctor degree in Chinese Academy of Sciences in 1986. He specializes in ice core and cold regions environment and has obtained much achievement in relation to the studies of ice core and historical climatic variations in Tibetan Plateau. .As a professor and chief scientist between 1990 and 2000, he has successfully organized and completed several key research projects dealing with ice core and climatic changes in western China.

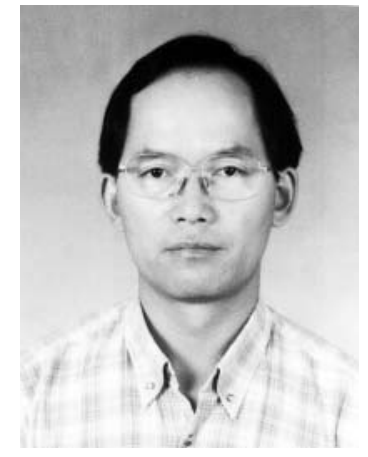

Professor Cheng Guodong is an academician of Chinese Academy of Sciences and titular member of Chinese Society of Glaciology and Geocrydogy. His research interests focus on earth's cryospheric changes and their impact on resources and environment in cold regions. He has achieved a lot in studying snow, ice and frozen ground during the past 25 years and is currently managing several national programs relating to crysopheric behaviors and water resorces in western China.

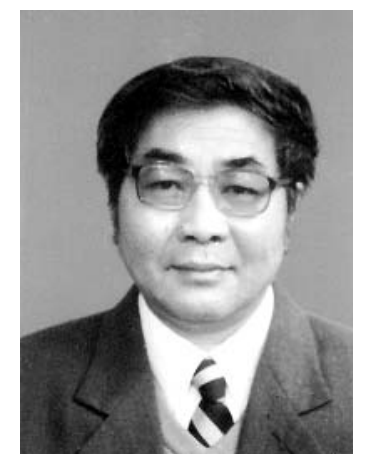

Su, Z., and Wang, L,1996, The development conditions, number and morphological characteristics of the glaciers in Hengduan Mountains, in:

Z., and Pu J., 1996. Characteristics of ablation, hydrology and hydrogeoHengduanshan Range, pp.1-25

Wagenbach, D., 1989. Environmental records in alpine glaciers, In: The envi-

Wang Yay) Chichester. Wiley-Interscience, pp. 69-83.

ogy Press, Beijing,. pp.1-121. nal, v.64, no.3, pp.222-231. Geological Society of China, v.17, no.4, pp.145-168. pp. 46-50

Xie, Y. and Cui, Z., 1989, Mt. Yulong in northern Yunnan, in: The glaciation Press, pp.106-119.

Yo, X., Qu, Y., and $\mathrm{Li}, \mathrm{T} ., 1999$, The glaciation in eastern part of $\mathrm{Mt}$. $242-248$.

2000. The evolution model of the Quaternary glaciation and tourism valuation of the glaciers in Mt. Yulong: Journal of Glaciology and Geocryology, v.22, no.1, pp. 68-73. 